\title{
MONITORING OF ORCHID POPULATION IN THE AREA OF PIERZCHNO, COUNTY OF ŚRODA WIELKOPOLSKA (WIELKOPOLSKA)
}

\author{
Magdalena Kluza-Wieloch, Sara Owczarek \\ M. Kluza-Wieloch, Department of Botany, Poznań University of Life Sciences, Wojska Polskiego 71 C, \\ 60-625 Poznań, Poland, e-mail: kluza@up.poznan.pl
}

(Received: June 29, 2015. Accepted: July 24, 2015)

\begin{abstract}
AвSTRACT. The subject of the research was the population of orchid growing in the area of Pierzchno in Wielkopolska. This position was found in 2001 where two kinds of orchids were recorded - Orchis morio and Dactylorhiza majalis. Male orchid occurs in the particular position in this geographical region. Quite numerous population of Dactylorhiza majalis (broad-leaved marsh orchid) and counting only a few specimens of the population of Orchis morio were followed in 2013-2015. The research concerned both individual and group features. During this period, we observed a clear progression of broad-leaved marsh orchid population. It resulted in an increase in the number of ramets and the area occupied by it. In the first year of research two experimental plots were extracted and in the next growing season, a third surface was found, occupied by the species. Locating juveniles in the second season also confirms the population dynamics. In the last year of observation, orchids appeared only on the second surface, which substantially increased its dimensions. Unfortunately, in the case of populations of the male orchid clear regression was noted because fewer individuals grew from year to year. On the meadow nearby Pierzchno favourable living conditions were found for Dactylorhiza majalis and unfavourable ones for Orchis morio, which could lead to the disappearance of this population.
\end{abstract}

KeY WORDS: Orchis morio, Dactylorhiza majalis, population, individual features, group features, Pierzchno

\section{INTRODUCTION}

Generally, orchids (orchidee) are united with epiphytes, plants, whose life-cycle takes place without contact with the surface of the soil. This is the dominant form of life in the tropics. However, in temperate climates such orchids would not survive due to low temperatures, or long periods of drought. Therefore, in such areas, including Poland, they take the form of geophytes. Worldwide, the number of species of orchids is estimated in the range of 20-35 thousand, while the flora of our country represents only 46 taxa (SzlachetKo and SKakuj 1996). In Wielkopolska region there are far fewer of them - only 11 species, of which seven belong to the group rarest taxa in the country (CZARNA 2009).

Due to the locus, orchids are divided into three main groups. Some of them belong to the species of deciduous forests - primarily beech and hornbeam, the second ones grow in coniferous forests and oth- er species are photophilous orchids, occurring in the meadows and bogs (SzlachetKo \& SKakuj 1996). Both taxa, referred to in this study - Orchis morio L. and Dactylorhiza majalis (Rchb.) P.F. Hunt \& Summerh are precisely the latter group.

Orchis morio (male orchid) is present in Europe, except in Spain and almost whole Scandinavia (PięKoś-Mirkowa \& Mirek 2003), and North Africa. It is rare also in the Caucasus and in Iran (Baumann et al. 2010). In Poland, this orchid is seen in few places. Male orchid grows in meadows and forests overexposed. It prefers fresh soil, moderately fertile, neutral (SZlachetKo \& SkAKUJ 1996).

Orchis morio (male orchid) is rare also in the Caucasus and in Iran (BAUMANN et al. 2010). In Poland, this orchid is seen in few places. Male orchid grows in meadows and forests overexposed.

Dactylorhiza majalis (broad-leaved marsh orchid) also encompasses large areas of Europe. The southern border of occurrence of this orchid continues 
through Northern Spain and Italy, to Croatia and Romania. Whereas, the northern border runs through southern Norway and Sweden (BAUMANn et al. 2010). In the last few years we have also seen the expansion of this species in Canada as a result of unconscious transfers (ADAMOwsKi 2008). In Poland, the broadleaved marsh orchid is quite popular and appears all over the country. It belongs to the photophilous species. The place of its occurrence are wet meadows, grasslands and swamps coastal headwaters. It grows on soils poor in calcium (BAUMANN et al. 2010).

The aim of the study was the monitoring of populations of male orchid and Dactylorhiza majalis occurring in the vicinity of Pierzchno. Their individual and group features were analysed and compared, while defining the conditions of existence and the state of danger. The data obtained were confronted with the results of other authors publications.

\section{METHODS}

Observations of Orchis morio and Dactylorhiza majalis populations were conducted in the Wielkopolski Lake District, in the community and the district of Środa Wielkopolska (Wielkopolska region), in the village Pierzchno (Fig. 1), on the grounds of utility, in the square ATPOL - CD 20. These species are located on a large complex of meadows of the Anthyllidi-Trifolietum montani team (CZARNA 2002), near which is a railway earthwork is located. This place is situated at a distance of about $2 \mathrm{~km}$ west from the railway station of Pierzchno. The area (terrain) is varied there. Lower parts of meadows are wet, thus the orchids grow on their drier parts.

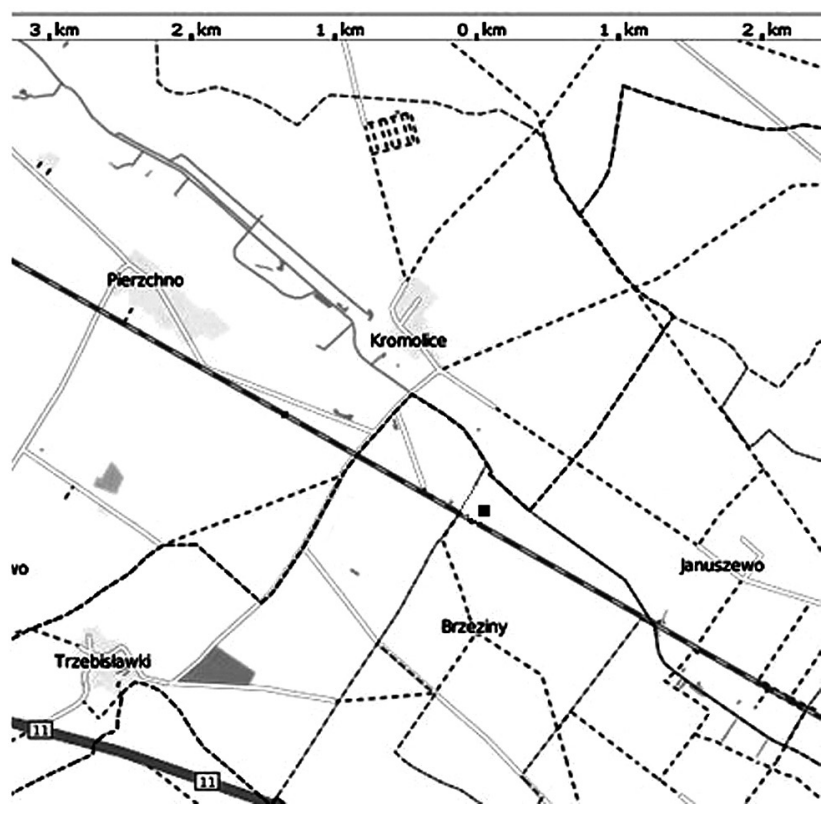

Fig. 1. Location of both populations on the tested position around Pierzchno, GPS data: $52^{\circ} 15^{\prime} 27.2^{\prime \prime} \mathrm{N} 17^{\circ} 10^{\prime} 38.5^{\prime \prime} \mathrm{E}$
Observations of orchids included three growing seasons. Each time field work took place in May. In the years (2013-2014) individual features of the population were tested and group characteristics were analysed in years (2013-2015). In the first year of the study the two test surfaces were separated by a telegraph pole and the distance between them was $25 \mathrm{~m}$ in a straight line. In the following year a third position came out. It was away from the surface no. 2 of about 15 meters to the east. In 2015, no individual was reported on the plots no. 1 and 3. In contrast, the surface no. 2 has increased considerably in size.

Measurements of individual features of each ramet included: the height of the shoot, inflorescence length, number of flowers, number of leaves, length and width of the largest leaf and bract length and width. For these parameters: arithmetic mean, standard deviation and coefficient of variation were calculated. The minimum and maximum of the particular feature was also determined (BUGA \& KASSYK-ROKICKA 2008). In the case of a small population of Orchis morio (3-6 individuals), only the results of the arithmetic mean and minimum and maximum values were given. The bract size for this species was also not measured. The following group features were studied: population size, density of individuals per $1 \mathrm{~m}^{2}$ (minimum, maximum and average) and the congestion factor (ColLIER et al. 1978) and the coefficient of dispersion (Trojan 1975). Naming of species taken as MireK et al. (2002).

\section{RESULTS}

The values of individual characteristics of Dactylorhiza majalis population are summarized in Table 1. The shoots developed in the range of $9-33 \mathrm{~cm}$, whereas in 2014 the maximum value of this feature was only $17.2 \mathrm{~cm}$. The average height of flowering specimens has declined significantly, although the value of the coefficient of variation in the two years of observation remained at the level of the average differentiation. The average length of inflorescence ranged from 4.29 to $4.90 \mathrm{~cm}$. It reached a maximum of $7.7 \mathrm{~cm}$. Individuals at plot no. 1 were characterized by the lowest variability of this trait. In turn, the number of flowers per inflorescence (3-27) changed most significantly at the second position. In 2013 it was at the level of low diversity $(6.41 \%)$. In the next growing season, the value was $30.98 \%$. Tested ramets usually have four leaves, although in the first year specimens with only three of these organs appeared. This feature was characterized by a small variation of coefficient of variation. The average dimensions of the length of the largest leaf developed in the range of 4.3-14.7 $\mathrm{cm}$ and decreased in the second season of observation. However, a higher variability of the data was observed then. The width of these leaves annually followed a similar pattern, with an average 
Table 1. Individual features of Dactylorhiza majalis population

\begin{tabular}{|c|c|c|c|c|c|c|c|c|c|c|c|}
\hline \multirow{3}{*}{ Feature } & \multirow{3}{*}{$\begin{array}{c}\text { Study } \\
\text { area }\end{array}$} & \multicolumn{5}{|c|}{2013} & \multicolumn{5}{|c|}{2014} \\
\hline & & \multicolumn{3}{|c|}{ value } & \multirow{2}{*}{$\mathrm{SD}$} & \multirow{2}{*}{ V (\%) } & \multicolumn{3}{|c|}{ value } & \multirow{2}{*}{$\mathrm{SD}$} & \multirow{2}{*}{$\mathrm{V}(\%)$} \\
\hline & & M & min. & $\max$. & & & M & $\min$. & $\max$. & & \\
\hline \multirow{3}{*}{ Height of plant $(\mathrm{cm})$} & 1 & 21.63 & 9.5 & 33.0 & 5.94 & 27.48 & 12.34 & 9.0 & 17.2 & 2.91 & 23.58 \\
\hline & 2 & 21.75 & 11.0 & 32.5 & 5.75 & 26.44 & 16.27 & 8.2 & 25.5 & 4.63 & 28.46 \\
\hline & 3 & - & - & - & - & - & 15.67 & 9.8 & 28.5 & 3.99 & 25.46 \\
\hline \multirow{3}{*}{ Length of inflorescence $(\mathrm{cm})$} & 1 & 4.90 & 3.5 & 6.5 & 0.82 & 16.75 & 4.29 & 3.7 & 5.8 & 0.66 & 15.38 \\
\hline & 2 & 4.59 & 3.0 & 6.5 & 1.00 & 21.78 & 4.80 & 3.5 & 7.7 & 1.06 & 22.08 \\
\hline & 3 & - & - & - & - & - & 4.57 & 3.0 & 7.0 & 0.98 & 21.44 \\
\hline \multirow[t]{3}{*}{ Number of flowers } & 1 & 15.35 & 10 & 21 & 3.10 & 20.19 & 14.13 & 9 & 18 & 3.44 & 24.01 \\
\hline & 2 & 14.73 & 3 & 23 & 4.79 & 6.41 & 16.27 & 7 & 27 & 5.04 & 30.98 \\
\hline & 3 & - & - & - & - & - & 15.10 & 6 & 26 & 4.31 & 28.54 \\
\hline \multirow[t]{3}{*}{ Number of leaves } & 1 & 3.95 & 3 & 5 & 0.69 & 17.38 & 4.50 & 4 & 5 & 0.53 & 11.78 \\
\hline & 2 & 4.05 & 3 & 5 & 0.58 & 14.32 & 4.65 & 4 & 6 & 0.63 & 13.55 \\
\hline & 3 & - & - & - & - & - & 4.80 & 4 & 6 & 0.61 & 12.70 \\
\hline \multirow{3}{*}{ Lenght of the biggest leave $(\mathrm{cm})$} & 1 & 11.58 & 9.0 & 14.5 & 1.70 & 14.65 & 9.04 & 8.1 & 10.8 & 0.93 & 10.29 \\
\hline & 2 & 11.62 & 9.0 & 14.5 & 1.57 & 13.51 & 10.67 & 4.3 & 14.7 & 2.50 & 23.43 \\
\hline & 3 & - & - & - & - & - & 9.05 & 4.5 & 13.3 & 1.87 & 20.66 \\
\hline \multirow[t]{3}{*}{ Width of the biggest leave $(\mathrm{cm})$} & 1 & 2.72 & 1.7 & 3.8 & 0.48 & 17.64 & 2.66 & 2.4 & 3.3 & 0.34 & 12.78 \\
\hline & 2 & 2.47 & 1.5 & 3.7 & 0.62 & 25.10 & 2.83 & 2.0 & 4.9 & 0.79 & 27.92 \\
\hline & 3 & - & - & - & - & - & 2.59 & 1.9 & 4.7 & 0.59 & 22.78 \\
\hline \multirow[t]{3}{*}{ Length of bract $(\mathrm{cm})$} & 1 & 2.57 & 2.0 & 3.1 & 0.37 & 14.40 & 2.43 & 2.1 & 2.8 & 0.25 & 10.29 \\
\hline & 2 & 2.40 & 2.0 & 2.9 & 0.29 & 12.08 & 2.82 & 2.0 & 4.5 & 0.67 & 23.76 \\
\hline & 3 & - & - & - & - & - & 2.29 & 1.6 & 3.8 & 0.43 & 18.78 \\
\hline \multirow[t]{3}{*}{ Width of bract $(\mathrm{cm})$} & 1 & 0.57 & 0.3 & 0.9 & 0.14 & 24.56 & 0.65 & 0.5 & 0.8 & 0.09 & 13.84 \\
\hline & 2 & 0.67 & 0.5 & 0.9 & 0.14 & 20.90 & 0.68 & 0.5 & 1.2 & 0.19 & 27.94 \\
\hline & 3 & - & - & - & - & - & 0.62 & 0.4 & 0.9 & 0.11 & 17.74 \\
\hline
\end{tabular}

$\mathrm{M}$ - arithmetic average, SD - standard deviation, $\mathrm{V}$ - coefficient of variation.

of $2.47-2.82 \mathrm{~cm}$. Bract dimensions were comparable in the years of the research and were around $2.5 \mathrm{~cm}$ long and $0.6 \mathrm{~cm}$ wide.

Table 2 summarizes the characteristics of the Dactylorhiza majalis population group. In 2014 the position no. 1 decreased its area from $48 \mathrm{~m}^{2}$ to $32 \mathrm{~m}^{2}$. Similarly, the number of individuals has changed (from 20 to 13). Tested ramets were dispersed, and in 2015 there has been no individual reported. The situation was different at plot no. 2, where orchids have spread significantly. Initially, 22 individuals were located there. In the current year (2015) the number has risen to 130 . The average congestion and dispersion coefficient were variable. In contrast, the position no. 3 discovered in 2014, was characterized by the highest values of the average congestion (5.24) and coefficient of dispersion (6.15) although it occurred only once. In $170 \mathrm{~m}^{2}, 158$ plants were found.
The observed results of individual characteristics of Orchis morio are shown in Table 3. In 2013, the population was six ramets. In the following seasons only three orchids were observed. In 2013, the amount of sprout ranged from 19-25 cm with an average of $22.95 \mathrm{~cm}$. The following season, the above-mentioned range has increased and amounted to $12.5-28$ $\mathrm{cm}$ (average $19.33 \mathrm{~cm}$ ). The length of inflorescence has also increased, and in 2014 was $3.5-6.2 \mathrm{~cm}$. However, the average length of the characteristic has fallen from 5.03 to $4.4 \mathrm{~cm}$. The maximum number of flowers (12) was recorded in the first year of the follow-up (average 8.33). The following season, the maximum number was nine. A minimum number of leaves was one - in 2013, with a maximum of seven - the following year. The average was 4.33 leaves in the first year of the study and 5.67 in the second one. The length of the largest leaf ranged from $4.5-8.5 \mathrm{~cm}$

Table 2. Group features of Dactylorhiza majalis population

\begin{tabular}{|c|c|c|c|c|c|c|c|c|}
\hline \multirow{3}{*}{ Study area } & \multirow{3}{*}{ Year } & \multirow{3}{*}{$\begin{array}{l}\text { Size of the } \\
\text { study area } \\
\qquad\left(\mathrm{m}^{2}\right)\end{array}$} & \multicolumn{6}{|c|}{ Feature } \\
\hline & & & \multirow{2}{*}{$\begin{array}{c}\text { number of } \\
\text { plants }\end{array}$} & \multicolumn{3}{|c|}{ density $\left(\mathrm{N} / \mathrm{m}^{2}\right)$} & \multirow{2}{*}{$\begin{array}{c}\text { average } \\
\text { congestion }\end{array}$} & \multirow{2}{*}{$\begin{array}{l}\text { dispersion } \\
\text { factor }\end{array}$} \\
\hline & & & & average & $\min$. & $\max$. & & \\
\hline \multirow{3}{*}{1} & 2013 & 48 & 20 & 0.42 & 1 & 4 & 0.70 & 1.30 \\
\hline & 2014 & 32 & 13 & 0.41 & 1 & 2 & 0.46 & 1.08 \\
\hline & 2015 & - & - & - & - & - & - & - \\
\hline \multirow{3}{*}{2} & 2013 & 16 & 22 & 1.38 & 1 & 4 & 1.27 & 0.95 \\
\hline & 2014 & 120 & 29 & 0.24 & 1 & 3 & 0.76 & 1.54 \\
\hline & 2015 & 384 & 130 & 0.34 & 1 & 9 & 1.54 & 2.84 \\
\hline \multirow{3}{*}{3} & 2013 & - & - & - & - & - & - & - \\
\hline & 2014 & 170 & 158 & 0.93 & 1 & 17 & 5.24 & 6.15 \\
\hline & 2015 & - & - & - & - & - & - & - \\
\hline
\end{tabular}


Table 3. Individual features of Orchis morio population

\begin{tabular}{|c|c|c|c|c|c|c|}
\hline & \multicolumn{3}{|c|}{2013} & \multicolumn{3}{|c|}{2014} \\
\hline & average & $\min$. & $\max$. & average & min. & $\max$. \\
\hline Amount of momentum $(\mathrm{cm})$ & 22.95 & 19.0 & 25.0 & 19.33 & 12.5 & 28.0 \\
\hline Length of the inflorescence $(\mathrm{cm})$ & 5.03 & 4.0 & 5.7 & 4.40 & 3.5 & 6.2 \\
\hline Number of flowers & 8.33 & 4 & 12 & 7.33 & 5 & 9 \\
\hline Number of leaves & 4.33 & 1 & 6 & 5.67 & 5 & 7 \\
\hline Length of the biggest leaf $(\mathrm{cm})$ & 6.00 & 4.5 & 8.5 & 6.23 & 5.5 & 7.5 \\
\hline Width of the biggest leaf $(\mathrm{cm})$ & 1.00 & 0.7 & 1.2 & 1.30 & 1.0 & 1.6 \\
\hline
\end{tabular}

and was on average around $6 \mathrm{~cm}$. Its width was in the range of $0.7-1.6 \mathrm{~cm}$. Both of these features were slightly higher in the second year of the study.

Analysing the group features of Orchis morio in the first year of observation, six individuals of this species were found. They grew at a great distance from each other. In the next season, the number has fallen by half. In 2015, three ramets of the orchid has been noted, however they were located close to each other, on an area of $1 \mathrm{~m}^{2}$. Every time they grew nearby plot no. 2 (the position of population of Dactylorhiza majalis).

\section{DISCUSSION}

According to Bernacki (1998) the number of broad-leaved marsh orchid is usually between 1-30 individuals, rarely 100 . He also observed a decrease in the number of posts and the number of populations in the region of the Silesian Upland (Wyżyna Śląska). In the first year of the study, two surfaces of orchids numbering about 20 individuals on each of them were found in the surrounding of Pierzchno. Next year, another position with more than 150 specimens was found. Moreover, some young and yet not blooming individuals were observed. This may indicate the development of the population. It should also be noted that this was not a one-time mass appearance and the blooming of the broadleaved marsh orchid due to the respective weather conditions, as mentioned CioseK et al. (1999). In the Nadwarciański Landscaped Park, in the vicinity of Pyzdry, KRUPA \& KRUPA (2011), while specifying the number of populations occurring, drew their attention to the numerous positions of Dactylorhiza majalis., they drew attention to the numerous positions Dactylorhiza majalis. Among the 16 areas populations numbering up to 6,000 individuals were spotted. The authors (KRUPA \& KRUPA 2011) stressed the need to preserve wetland ecosystems, as well as mowing meadows, without which overgrowing of the positions with reed will cause the disappearance of the positions. However, the owners of the land used for cutting should take into account the dates of flowering and fruiting of the protected orchids. In the case of positions in the area of Pierzchno, where Dactylorhiza majalis and Orchis morio have a similar period of flowering, there is no such a problem. It is said that the first mowing is done here until June. Moreover, moist areas, partly flooded, also indicate favourable living conditions for the population of broad-leaved marsh orchid, which is located in close proximity to water. The relationship between good looks of the specimens and humidity of the substrate is also noted (Kolon 1995). The higher the meadows, the smaller individuals were found. Although the broadleaved marsh orchid is a common species occurring in Poland, Bernacki (1998) emphasizes that, in the region of Upper Silesia, category V - "exposed" was granted to it. It is connected to the strong urbanization. In turn, KLUZA-WIELOCH \& BEDNORZ (2011) claim that the main threat for orchids growing in Poznan, in addition to increasing anthropogenic pressure, is to restricted access to light as a result of overgrowing their positions with high herbs or shrubs. The authors also described the orchid position on the former ecological use ground of "Psarskie" in Poznan, which has been seriously jeopardized because of the acquisition of land by a private owner. KLUZA-WIELOCH \& Bednorz (2010/2011) emphasized the need to develop a regime for transfer of environmentally valuable land plots to the owners and the need to impose on them the duty of not interfering in the population of valuable habitat. The research in the variability of morphological traits in 17 populations of Dactylorhiza majalis in Pomerania (Pomorze Gdańskie) has also beed led by NACZK (2011). Differences in average values for each feature could be related to the often observed phenotypic plasticity of this species, due to its adaptation to local site conditions. At present, WolANIN \& OKLejewicz (2011) have found this species in Przemyskie Foothills (Pogórze Przemyskie) at 11 positions. In the valley of the San two large populations of orchids have also been recorded (OKLEJEWICZ et al. 2008). Trąa et al. (2008) studied the broad-leaved orchids on the Kolbuszowa plateau. It grew there in two groups of plants and five different communities, on moist soils and wetlands. In the Białowieża National Park, this taxon can also be found at several positions, of which the most numerous counts more than 50 individuals (KARCZEWSKA 2011). It frequently occurs in the positions of anthropogenic origin, e.g. along forest roads and ditches. According to information from the Biebrza National Park, the Dactylorhiza majalis counts large numbers throughout the area (WeRpachowsKi 2008). PoKoRNy (2008) reported 
that broad-leaved marsh orchid is present in Sudety mountains on more than 70 positions and is considered to be a common species in grassy communities.

The decreasing number of ramets of male orchid in the area of Pierzchno arouses more anxiety. In the second and third year of the study, it fell by half and totaled only three specimens, however they were significantly dispersed on the surface. Considering the fact that in 2001, 30 individuals were recorded on only $8 \mathrm{~m}^{2}$ (CZARNA 2002), it can be assumed that this species has a tendency to extinction. To prevent the loss of the gene pool of this population, it would be necessary to take drastic action. With the consent of the owner of the meadow, it would be needed lead to fruiting of ramets, and from the received seed (through in vitro method), multiply the plant material and reintroduce it to a natural environment. Perhaps not without significance was the variability of weather conditions in recent years. In 2013, and 2015 years the beginning of spring delayed, while in 2014 it occurred much earlier. Moreover, both species flowering in the second year of the study was somewhat accelerated. Orchis morio position is currently the only one existing in the Wielkopolska as described by NowaK (1999), similarly to the position of the Silesian Upland. Despite large fluctuations in numbers even up to 250 flowering individuals have appeared there. PoкоRNY (2008) reported that this species occurs in the Sudety mountains in only few places and is considered as a very rare species found in grassland communities. The new and, so far, the only place of occurrence of male orchid in the Przemyskie Foothills, was described by Wolanin \& Oklejewicz (2011) and Hatucha (2012). The second author stressed the need to establish protection for that place in the form of ecological use. In the case of grassland in the area of Pierzchno, Czarna (2002) has also paid attention to the same aspect. Hatucha (2012) also presented the problem of digging out and moving plants to home gardens from their former position between Dąbrowa Górnicza and Sławków. This situation is also possible in Pierzchno, where broken sprouts of Dactylorhiza majalis were observed.

The results of the research of Dactylorhiza majalis population in Pierzchno were compared to the other measurements of this species, growing on Polish territory. The height of flowering stems of broad-leaved marsh orchid specimens ranged within the range administered for this species (SzLachetKo \& SKAKUJ 1996). However, smaller plants were noted here, both in terms of minimum and maximum values, and the arithmetic mean, compared to the results of research carried out in Hutyrowa in Żywiecki Landscape Park (Rudecki \& Sporek 1995), and in Siedmica in the Kaczawskie Mountains (MArczoneK et al. 1995). Smaller length of inflorescences was also observed in comparison to the data presented by the other authors. In the area of Pierzchno the maximum value was $7.7 \mathrm{~cm}$, while RUdeCKI and SPOREK (1995) recorded a $14.5 \mathrm{~cm}$ inflorescences with the maximum number of 47 flowers. However, the longer the bunch, measured in Siedmica, did not always have more flowers than in broad-leaved orchid, in the area of Pierzchno. This may indicate that in Pierzchno inflorescences were more compact than in research MarczoneK et al. (1995). In the plots of Pierzchno up to six leaf were observed in Dactylorhiza majalis which is consistent with the description of SzLAснетко \& SKakuj (1996). Most often, however, from 4 to 5 leaves appeared. On the other hand, RUDECKI \& SPOREK (1995) reported up to eight leaves. Although the obtained values of the maximum length of the longest leaf in Siedmica and in Hutyrowa were higher than in the Wielkopolska, a higher mean value of this characteristic has been reported here. The same situation occured for measuring a width of the largest leaf. Bract sizes were smaller than given in RUDECKI \& SPOREK (1995), but comparable with the values given in SARosieK \& WożaKowSKA-NatKANIEC (1994).

In May 2009, KluZA-Wieloch \& Bednorz (2010/2011) conducted a study on population of broad-leaved orchid, located within ecological site of the former "Psarskie" in the north-western part of Poznań. Orchids occurred on a wet meadow at the position of an area of $170 \mathrm{~m}^{2}$. The number of plants of flowering specimens was 31 which was not a very large population compared to that of the surrounding of Pierzchno. Orchids from the former ecological use called "Psarskie" reached a height of 24.0 to 52.2 $\mathrm{cm}$ (average $35.6 \mathrm{~cm}$ ). And the average inflorescence was $6.8 \mathrm{~cm}$ in length (minimum $4.0 \mathrm{~cm}$, up to 11.5 $\mathrm{cm})$. Thus, they were characterized by longer shoots and florets. KluZA-Wieloch \& BedNorz (2010/2011) reported that on one plant grew from 3 to 7 leaves (average of 3.8), and the inflorescence was composed on average of nearly 15 (14.8) single flowers (minimum 9, maximum 32). Measurements made in the area of Pierzchno were similar in the case of the number of flowers, and orchids growing here had more leaves. The biggest broad-leaf population, occurring in the former of ecological "Psarskie", achieved an average of $11.1 \mathrm{~cm}$ in length (from 7.0 to $16.0 \mathrm{~cm}$ ) and $2.8 \mathrm{~cm}$ wide $(1.9-4.5 \mathrm{~cm}$ ) while the dimensions of the subtending ranged from 1.8 to $3.8 \mathrm{~cm}$ in length (average $2.6 \mathrm{~cm}$ ) and from 0.3 to $0.9 \mathrm{~cm}$ wide (approximately $0.5 \mathrm{~cm}$ ). The results of these attributes presented in this study were quite similar. KluZA-Wieloch \& Bednorz (2010/2011) noted that the greatest variability was characterized by a number of leaves $(35.50 \%)$ and the width of the bract $(28.64 \%)$ and the lowest amount of momentum (18.04\%) and the length of bract $(21.19 \%)$. While in the test population over 2013-2015 coefficient of variation reached the highest value for the amount of shoots and number of flowers, and the smallest for the number of leaves. 
In June 2006, a study on population of broad-leaved orchid, in the Opawskie Mountains Landscape Park, in the Department of Mining and Milling of Slate in Jarnołtówek, was conducted, due to the need to transfer her to another position (SPOREK \& SPOREK 2009). The size of this population was higher than in Pierzchno and there were 207 individuals, including 109 flowering plants and 98 juvenile ones. The average shoot length was of $26.7 \mathrm{~cm}$ (11.0 to $47 \mathrm{~cm}$ ), as well as the average length of the inflorescence, which reached from 2.0 to $17.0 \mathrm{~cm}$ (approximately $6.4 \mathrm{~cm}$ ) were greater than presented herein population. The only feature that had less value than in orchids from around Pierzchno was the number of leaves. The coefficient of variation in observed characteristics in the Opawskie Mountains Landscape Park, was greater for the length of the inflorescence $(35.0 \%)$ and the number of leaves $(21.09 \%)$ than in the population located in the district of Śrem, and the smaller the length of the shoot $(25.6 \%)$.

KozŁowski et al. (2009) characterized the two positions of broad-leaved orchid, located in the complex of meadows near the village of Chojna, near Sieradz (Lodz Upland - Wysoczyzna Łódzka). The average height of the plants on the position I was $15.8 \mathrm{~cm}$, and the position II $-21.3 \mathrm{~cm}$. It developed similarly to the population in Pierzchno. The values of the average length of inflorescence of the population located in the Lodz Upland (I $-5.4 \mathrm{~cm}$, II $-5.8 \mathrm{~cm}$ ) were higher than the results presented in this study, while the average number of leaves was slightly higher and amounted to the position I -4.7 and the position II - 5.3. Inflorescences of broad-leaved orchid populations located in Lodz Upland consisted of more flowers than in the subject population. The subject bunch consisted of an average of 15.6 individual flowers on the position I and 22.1 on the position II (KozŁowsKI et al. 2009).

In the area of Pierzchno Dactylorhiza majalis had the largest agglomeration on plot no. 3 , where a dozen individuals were observed in $1 \mathrm{~m}^{2}$. Frequently, however, specimens growing alone to a greater or lesser distance from one another occurred. In contrast to the work of Kolon (1995), who wrote about the decline of population due to reduced acreage available for broad-leaved orchid around Pierzchno have increased the area of their occurrence and the total number of individuals, but from year to year underwent a greater dispersion. In contrast, comparing the characteristics of the population of Dactylorhiza majalis on the former use of environmentally friendly "Psarskie" in Poznań, which was investigated by KluZA-Wieloch \& Bednorz (2010/2011), with a population of orchids in the area of Pierzchno, the differences in both average density of plants per $1 \mathrm{~m}^{2}(0,18$ individual), where a maximum of $1 \mathrm{~m}^{2}$ grow three orchids, as well as congestion average coefficient expressed Lloyd were noted.
The above-mentioned authors obtained lower values of these characteristics in comparison with the group presented in this paper. The spatial structure of the population, located on the former use of environmentally friendly "Psarskie" was the type of agglomeration one (KLUZA-Wieloch \& BednoRz 2010/2011). The results can be compared also in terms of the number and percentage of plants in generative and vegetative stages of development, from research conducted in Krowiarki in the East Sudety mountains (Czuluk 1999). The author conducted research in 1995 and 1998, described seven of this species located in the municipality of Bystrzyca Kłodzka, in the Piotrowice, Old Waliszów and New Waliszów villages. In terms of the size of populations they ranged from 0 (title II, III, VI in 1998) to 301 subjects (position $\mathrm{V}$ in 1995). The largest share of flowering plants in the population, amounting to $100 \%$, determined in 1998 in the population IV and VII, and the lowest (46\%) as the IV in 1995.

Comparing the amount of shoots at Orchis morio, given by SzLACHETKO \& SKAKUJ (1996), observed in Wielkopolska, quite tall specimens of this species with a small number of leaves were found. While Szlachetкo \& SKaKUJ (1996) show the range from 6 to 10 , in the vicinity of Pierzchno only seven of them were observed. Ramets with one leaf have also occurred. Both the length and the width of the largest leaves were at a medium level. There was also a long, but not too dense inflorescence, as a maximum number of flowers was 12 .

\section{CONCLUSIONS}

1. In the case of Dactylorhiza majalis population growth trends were observed.

2. Orchis morio population showed a downward trend, which in the future could threaten its extinction and at the same time, if nothing is done, it may result in the lack of male orchid position in Wielkopolska.

3. The broad-leaved marsh orchid at the third position was characterized by the greatest abundance and density per unit area. Populations of this species in positions 1 and 2 were more dispersed.

4. On the designated research areas the average height of shoots of Dactylorhiza majalis in subsequent years of observation has decreased.

5. Moreover, Orchis morio average values of the most important individual characteristics (height shoots, inflorescences length and number of flowers) decreased.

6. In years of the research, the most variable trait in the population of the broad-leaved orchid was the height of canes, while the smallest variability was characterized by a number of leaves.

7. In 2014, apart from specimens of Dactylorhiza majalis in generative phase, juvenile specimens were 
observed. It can provide for the development of the population.

\section{REFERENCES}

AdAMOWSKi W. (2008): Storczyki na emigracji. In: E. Brzosko, A. Wróblewska, I. Tałałaj (eds). Problemy badawcze i perspektywy ochrony storczykowatych $\mathrm{w}$ Polsce. Uniwersytet $\mathrm{w}$ Białymstoku, Osowiec-Twierdza: 7-16.

Baumann H., KünKele S., Lorenz R. (2010): Storczyki Europy i obszarów sąsiednich. Multico Oficyna Wydawnicza, Warszawa.

BERNACKI L. (1998): Materiały do atlasu rozmieszczenia oraz stanu zasobów roślin chronionych i zagrożonych rejonu górnośląskiego - PRESS. Część 3. Dactylorhiza majalis (Rchb.) P.F. Hunt et Summerh. (Orchidaceae). Acta Biologica Silesiana 33: 95-112.

Buga J., Kassyk-Rokicka H. (2008): Podstawy statystyki opisowej. Vizja Press \& IT, Warszawa.

Ciosek M., Trzpil-Zwierzyk B., Piotrek K. (1999): Masowe kwitnienie stoplamka szerokolistnego Dactylorhiza majalis na łąkach koło Wyszkowa. Chrońmy Przyrodę Ojczystą 55: 94-95.

Collier B.D., Cox G.W., Johnson A.W., Miller P.C. (1978): Ekologia dynamiczna. Państwowe Wydawnictwo Rolnicze i Leśne, Warszawa.

CZARna A. (2002): Obecność Orchis morio L. na terenie Wielkopolski. Roczniki Akademii Rolniczej w Poznaniu 347, Botanika 5: 23-25.

CzArna A. (2009): Rośliny naczyniowe środkowej Wielkopolski. Wydawnictwo Uniwersytetu Przyrodniczego, Poznań.

Czuluk J. (1999): Stan populacji kukułki szerokolistnej Dactylorhiza majalis w Krowiarkach (Sudety Wschodnie) w latach 1995 i 1998. Przegląd Przyrodniczy 10, 3-4: 151-156.

Hatucha P. (2012): Nowe stanowisko Orchis morio (Orchidaceae) na Pogórzu Przemyskim. Fragmenta Floristica et Geobotanica Polonica 19: 547-549.

KarCZewsKa M. (2011): Storczykowate (Orchidaceae) Białowieskiego Parku Narodowego - stan zachowania i sposoby ochrony. In: E. Brzosko, A. Wróblewska, E. Jermakowicz (eds). Storczykowate $\mathrm{w}$ Polsce. Biologia i ochrona. Wojewódzki Fundusz Ochrony Środowiska i Gospodarki Wodnej w Białymstoku, Uniwersytet w Białymstoku, Białystok: 95-98.

KluZa-Wieloch M., Bednorz L. (2010/2011): Stanowisko kukułki szerokolistnej - Dactylorhiza majalis i kukułki krwistej - Dactylorhiza incarnata na terenie dawnego użytku ekologicznego Psarskie w Poznaniu. Acta Scientarum Polonorum, Biologia 10-11 (1-4): 3-9.

Kluza-Wieloch M., Bednorz L. (2011): Aktualny stan, zagrożenia i problemy ochrony storczykowatych na terenie Poznania. In: E. Brzosko, A.
Wróblewska, E. Jermakowicz (eds). Storczykowate $\mathrm{w}$ Polsce. Biologia i ochrona. Wojewódzki Fundusz Ochrony Środowiska i Gospodarki Wodnej w Białymstoku, Uniwersytet w Białymstoku, Białystok: 99-105.

Kolon K. (1995): Dynamika liczebności populacji Dactylorhiza majalis (Rchb.) Hunt et Summerh. w Krzydlinie Wielkiej k. Wołowa. Acta Universitatis Wratislaviensis 1717, Prace Botaniczne 63: 79-89.

KozŁowski S., SwĘDRZyŃski A., WyłuPek T., WoźNiak R. (2009): Właściwości morfologiczne storczyków i ich występowanie w zbiorowiskach łąkowych. Łąkarstwo w Polsce 12: 97-110.

Krupa K., Krupa A. (2011): Materiały do znajomości storczykowatych Orchidaceae Nadwarciańskiego Parku Krajobrazowego. Przegląd Przyrodniczy 22: 3-14.

Marczonek A., Sarosiek J., Staszewska E. (1995): Ekologiczna charakterystyka populacji wybranych gatunków storczyków z Siedmicy w Górach Kaczawskich i warunków ich występowania. Acta Universitatis Wratislaviensis 1717, Prace Botaniczne 63: 5-25.

Mirek Z., PięKoś-Mirkowa H., Zając A., Zając M. (2002): Flowering plants and pteridophytes of Poland. A checklist. Krytyczna lista roślin naczyniowych Polski. W. Szafer Institute of Botany, Polish Academy of Sciences, Kraków.

NAczK A. (2011): Zmienność morfologiczna wybranych populacji Dacylorhiza majalis S.L. na Pomorzu Gdańskim. In: E. Brzesko, A. Wróblewska, E. Jermakowicz (eds). Storczykowate w Polsce. Biologia i ochrona. Wojewódzki Fundusz Ochrony Środowiska i Gospodarki Wodnej w Białymstoku, Białystok: 31-39.

NowAK T. (1999): Storczyk samiczy - rzadki gatunek na Wyżynie Śląskiej. Przyroda Górnego Śląska 15: 16.

Oklejewicz K., Trąba Cz., Wolański P. (2008): Orchidaceae $\mathrm{w}$ dolinie Sanu. In: E. Brzosko, A. Wróblewska, I. Tałałaj (eds). Problemy badawcze i perspektywy ochrony storczykowatych w Polsce. Biebrzański Park Narodowy, Uniwersytet w Białymstoku, Osowiec-Twierdza: 53-58.

PięKoś-Mirkowa H., Mirek Z. (2003): Atlas roślin chronionych. Multico Oficyna Wydawnicza, Warszawa.

PoKorny J. (2008): Storczykowate w warunkach siedliskowych Sudetów. In: E. Brzosko, A. Wróblewska, I. Tałałaj (eds). Problemy badawcze i perspektywy ochrony storczykowatych w Polsce. Biebrzański Park Narodowy, Uniwersytet w Białymstoku, Osowiec-Twierdza: 43-51.

RudeCKI A., SPOREK K. (1995): Ekologiczna charakterystyka populacji Dactylorhiza majalis (Rchb.) Hunt et Summerh. w Hutyrowej w Żywieckim 
Parku Krajobrazowym. Acta Universitatis Wratislaviensis 1717, Prace Botaniczne 63: 33-43.

Sarosiek J., WożaKowska-NatKaniec H. (1994): Ekologiczne zróżnicowanie populacji Dactylorhiza majalis (Rchb.) Hunt et Summerh. z okolic Jeleniej Góry na Dolnym Śląsku. Acta Universitatis Wratislaviensis 1717, Prace Botaniczne 59: 201-219.

Sporek M., Sporek K. (2009): Introdukcja kukułki szerokolistnej Dactylorhiza majalis (Rchb.) P.F. Hunt \& Summerh. w Parku Krajobrazowym Góry Opawskie. Chemia-Dydaktyka-Ekologia-Metrologia 14(1-2): 65-68.

Szlachetкo D., Skakuj M. (1996): Storczyki Polski. Sorus, Poznań.

Trąba Cz., Wolański P., OKlejewicz K. (2008): Występowanie Dactylorhiza majalis (Rchb.) P.F. Hunt \& Summerh w zbiorowiskach łąkowych Płaskowyżu Kolbuszowskiego (południowo-wschodnia Polska). In: E. Brzosko, A. Wróblewska, I. Tałałaj (eds). Problemy badawcze i perspektywy ochrony storczykowatych w Polsce. Biebrzański Park Narodowy, Uniwersytet w Białymstoku, Osowiec-Twierdza: 59-64.
Trojan P. (1975): Ekologia ogólna. PWN, Warszawa.

WerpachowsKi C. (2008): Storczykowate (Orchidaceae) Biebrzańskiego Parku Narodowego. In: E. Brzosko, A. Wróblewska, I. Tałałaj (eds). Problemy badawcze i perspektywy ochrony storczykowatych w Polsce. Biebrzański Park Narodowy, Uniwersytet $\mathrm{w}$ Białymstoku, Osowiec-Twierdza: 39-41.

Wolanin M., OkLejewicz K. (2011): Storczyki Pogórza Przemyskiego dawniej i dziś. In: E. Brzosko, A. Wróblewska, E. Jermakowicz (eds). Storczykowate w Polsce. Biologia i ochrona. Wojewódzki Fundusz Ochrony Środowiska i Gospodarki Wodnej w Białymstoku, Uniwersytet w Białymstoku, Białystok: 66-76.

For citation: Kluza-Wieloch M., OwczareK S. (2015): Monitoring of orchid population in the area of Pierzchno, county of Środa Wielkopolska (Wielkopolska). Steciana 19(3): 203-210. doi:10.12657/steciana.019.020 